\title{
Measurements of Emissions from Motorcycles and Modeling Its Impact on Air Quality
}

\author{
Lúcia F. A. Garcia, ${ }^{a, b}$ Sérgio M. Corrêa, ${ }^{*, a}$ Renato Penteado, ${ }^{c}$ Luiz Carlos Daemme, ${ }^{c}$ \\ Luciana V. Gattid and Debora S. Alvim
}

\author{
${ }^{a}$ Faculdade de Tecnologia, Universidade do Estado do Rio de Janeiro, 27537-000 Resende-RJ, Brazil \\ ${ }^{b}$ Instituto Estadual do Meio Ambiente, 20940-903 Rio de Janeiro-RJ, Brazil \\ 'Instituto de Tecnologia para o Desenvolvimento (LACTEC), 80210-170 Curitiba-PR, Brazil \\ ${ }^{d}$ Instituto de Pesquisas Energéticas e Nucleares, 05508-000 São Paulo-SP, Brazil
}

\begin{abstract}
O aumento do número de motocicletas nas grandes cidades brasileiras é decorrência de uma série de fatores, como o congestionamento, o baixo custo, mobilidade, poucos estacionamentos e transporte público deficiente, tornando-se um importante fator na deterioração da qualidade do ar. Neste contexto, o monitoramento das emissões veiculares é essencial para o entendimento da contribuição na poluição atmosférica. Neste cenário, foram amostradas as emissões de motocicletas em um ensaio dinamométrico e analisadas por cromatografia gasosa e analisadores automáticos de acordo com a Norma EC/97/24 (European Commission). As emissões das motocicletas usando gasolina comercial (com 22\% de etanol) foram usadas em combinação com dados meteorológicos e poluentes em ar ambiente para a cidade do Rio de Janeiro (Brasil) no período do inverno de 2011, empregando o modelo de trajetórias OZIPR (Ozone Isopleth Package for Research) e o modelo químico SAPRC99 (State-wide Air Pollution Research Centre) para avaliar o impacto na formação do ozônio na troposfera da cidade do Rio de Janeiro para os próximos anos. Os resultados indicam que os níveis de ozônio irão ultrapassar os limites estabelecidos pela legislação nacional dentro de três anos. O estudo também demonstrou que as taxas de emissão dos poluentes legislados atendem os níveis recomendados pela legislação brasileira para todas as fases propostas. O incremento nas concentrações de ozônio ocorre em função das elevadas emissões de compostos orgânicos voláteis reativos em uma atmosfera já com níveis elevados de óxidos de nitrogênio (NOx). Diante deste cenário, medidas adicionais são necessárias para o gerenciamento das emissões das fontes móveis.
\end{abstract}

The increase in the number of motorcycles in large Brazilian cities is due to several factors such as traffic, low cost, mobility, few parking lots and the low efficiency of public transportation, becoming an important factor in air quality deterioration. In this context, vehicle emissions monitoring is essential to understand the contribution to air pollution as a whole. In this scenario, the emissions were sampled on a motorcycle dynamometer test bench and analyzed by gas chromatography and on-line analyzers according to the EC/97/24 standard (European Commission). Emissions from motorcycles using commercial gasoline (with $22 \%$ of ethanol) were used in combination with meteorological data and ambient air pollutants for Rio de Janeiro City (Brazil) during the Winter of 2011, using the trajectory model OZIPR (Ozone Isopleth Package for Research) and the chemical model SAPRC99 (State-wide Air Pollution Research Centre) to assess the impact on the ozone formation in the troposphere of Rio de Janeiro for the next several years. The results indicate that ozone levels will exceed the established limits by national legislation within three years. The study also showed that pollutant emission rates stay in agreement with emissions recommended by the Brazilian legislation for all phases. The increase in ozone concentration occurs due to high emissions of reactive volatile organic compounds in an atmosphere with high levels of nitrogen oxides (NOx). Given this scenario, additional measures are necessary to manage emissions from mobile sources in the future.

Keywords: atmosphere, modeling, motorcycle, tropospheric ozone, volatile organic compounds

*e-mail: sergiomc@uerj.br 


\section{Introduction}

Concern with the environment is becoming a common issue in the society. The improvement of the air quality, mainly in large urban centers, is essential to the public health. However, anthropogenic activities, mainly from transport in large cities, combined with unfavorable weather conditions have contributed to an increase of pollutants in the atmosphere.

Global problems, such as the greenhouse effect, caused mainly by the release of undesirable compounds generated by human activity, justify the worldwide concern about this issue. Thus, the scientific community increasingly craves new technologies to understand and improve the composition of the atmosphere. Many of these technologies seek to control and monitor air quality.

Products of internal combustion engine vehicles can be considered one of the most polluting activities mainly due to the large number of vehicles in cities. The low quality and quantity of public transportation is one of several reasons for vehicle fleet growth in metropolitan regions. According to the latest report on air quality for the São Paulo State (Brazil), vehicles are responsible for $97 \%$ of $\mathrm{CO}, 77 \%$ of hydrocarbons (HC) emissions, $82 \%$ of nitrogen oxides (NOx), $36 \%$ of $\mathrm{SO}_{2}$ and $40 \%$ of particulate matter (PM). In addition, motorcycles contribute $16 \%$ of the total $\mathrm{CO}$ and $13 \%$ of the total HC. ${ }^{1}$

Motorcycles are a rising form of transportation in large cities across the world, especially in emerging countries such as China, India and Brazil. The intensive use of motorcycles is explained by their high mobility in increasingly congested cities that lack affordable public transport as a motorcycle with a less powerful engine $(150 \mathrm{cc})$ usually costs 20 to $25 \%$ that of a small car and is also associated with low fuel consumption, ease of parking and low maintenance cost. These advantages outweigh the inherent dangers of this form of transportation and other disadvantages such as interfering rain and the high cost of insurance. Brazil recorded 428,970 traffic accidents in 2008, the number of vehicles involved was 597,786 , of which 246,712 were cars and 200,449 were motorcycles. ${ }^{2}$

Given the facts presented and the potential increase in the amount of hydrocarbons in the atmosphere due to motorcycles, the net effect of ozone formation in cities such as Rio de Janeiro is also enhanced by high nitrogen oxide levels.

The large fleet growth in recent years, combined with high emission factors for such vehicles (caused by the absence of electronic fuel injection, catalysts and anti-evaporation systems), resulted in the need to implement more specific regulations. Thus, in February 2002, the
Program for the Control of Motorcycles and Related (PROMOT, CONAMA, Brazil), which established emission standards for three phases, was created. The first phase started in January 2003, the second phase started in January 2006 and the third phase started in January 2009. From the implementation of PROMOT, companies began to introduce technological improvements to suit pre-set limits to reverse the current degradation of air quality.

The experimental study of vehicle emissions, ambient air and meteorology, together with air quality modeling studies, is a powerful tool in forecasting scenarios. Scenarios for future situations mean that a locality can try, for example, to increase and/or change vehicle fleet and fuel composition and the occurrence of adverse weather events. ${ }^{3}$

To perform simulations of tropospheric ozone formation from motorcycle emissions, the trajectory model OZIPR (Ozone Isopleth Package for Research) coupled with the chemical model SAPRC (State-wide Air Pollution Research Centre) was used. ${ }^{4}$ Both are public domain, have wide acceptance in academia and international agencies and are relatively simple to work with. Moreover, its chemical mechanism is extremely detailed for photochemical reactions in the troposphere. The trajectory model OZIPR ${ }^{5}$ was developed by the United States Environmental Protection Agency (US EPA) as a support for the scenario forecasting of urban air pollution episodes. ${ }^{3,6,7}$

It is important to remember that the effect of a given emitted volatile organic compound (VOC) in ozone formation will depend not only on the VOC reaction rate and its reaction mechanism but also on the nature of the air where the VOC is emitted, including the effect of other pollutants and their concentrations. ${ }^{8}$

This study aimed to assess the overall impact of motorcycle emissions on air quality in large cities such as Rio de Janeiro by studying the profile of current fleets and estimates for future scenarios and identifying their emissions in classes of compounds.

\section{Experimental}

\section{Motorcycle emissions sampling}

Samples were collected during emission testing in a dynamometer bench (AVL Zöllner model AN 40 770, $648 \mathrm{~mm}, 100 \mathrm{~kW}$ ). The technical data on the motorcycles were sampled using the exhaust emissions of two motorcycles using commercial gasoline with $22 \% \mathrm{v} / \mathrm{v}$ of ethanol and are summarized in Table 1.

Tests were conducted over a chassis dynamometer according to the 97/24/EC (European Commission) drive cycle, which is divided into six primary modules and one 
Table 1. Motorcycle specifications

\begin{tabular}{lccccc}
\hline Motorcycle & Engine displacement $/ \mathrm{cm}^{3}$ & Emission regulation & Fuelling system type & Catalyst & Production year \\
\hline BK01 & 150 & Euro III & EFI & yes & 2009 \\
BK02 & 125 & Euro III & EFI & yes & 2009 \\
\hline
\end{tabular}

EFI: electronic fuel injection; BK01 and BK02 are the motorcycle codes used.

extra-urban cycle. Engines below $150 \mathrm{~cm}^{3}$ displacement were tested according to the 97/24/EC drive cycle and submitted to the six primary modules. Engines of up to 300 $\mathrm{cm}^{3}$ displacement were tested according to the 97/24/EC drive cycle and were submitted to six primary modules and one extra-urban cycle. Regulated emissions (CO, $\mathrm{HC}$ and NOx) were measured with 7000 series Horiba benches. Each cycle includes four modes (idling speed, acceleration, constant speed, deceleration, etc.). During the test, gases were diluted (1:20) with ambient air to obtain a mixture flow with constant volume. Throughout the test, a constant flow to a $90 \mathrm{~L}$ Tedlar bag was employed to successively determine the concentrations of $\mathrm{CO}, \mathrm{HC}$ and $\mathrm{NOx}$, which were then correlated to the distance travelled. A test procedure layout can be observed in Figure 1.

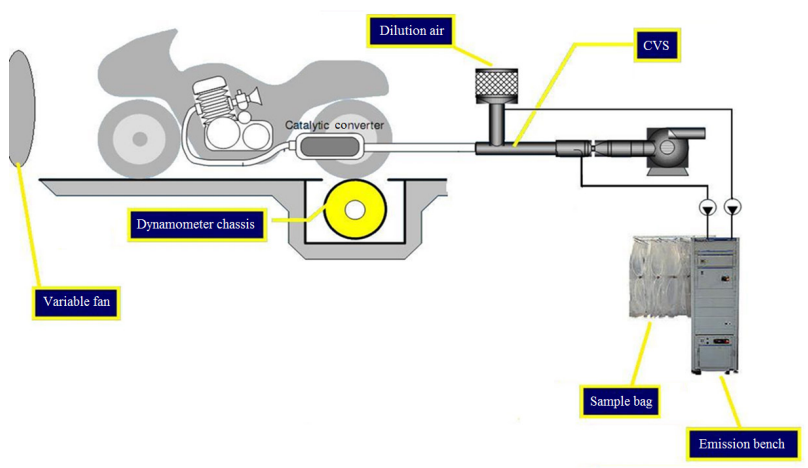

Figure 1. Test procedure layout.

For VOC speciation, $6 \mathrm{~L}$ canisters were used, which are spherical containers of stainless steel with electropolished inner surfaces. Prior to sampling, the canisters were cleaned using a cleaning system, which uses four cycles heated at $120^{\circ} \mathrm{C}$, an alternating dry and water vapor cycle and a high vacuum (Xontech model 960). Cleaning is completed upon placing the canister in a high vacuum $(<30$ mbar $)$, so that when the valve opens, the canister is filled with the $6 \mathrm{~L}$ sample.

\section{Analysis of criteria pollutants and VOC speciation}

For NOx measurement, a Trace LevelChemiluminescence NO- $\mathrm{NO}_{2-} \mathrm{NOx} 42 \mathrm{CTL}$ TEI model was used. For the measurement of $\mathrm{CO}$, a Filter Correlation $\mathrm{CO}$ Gas analyzer, model 48C TEI was used
The analytical methodology used for the VOC speciation followed the TO-TO-15 US EPA ${ }^{9}$ methodology with two gas chromatographs: one to analyze the hydrocarbons from $\mathrm{C} 2$ to $\mathrm{C} 5$ and one to analyze them from C6 to C12.

The VOC analyses were performed by passing a known volume through a cryogenic pre-concentrator trap $\left(-180{ }^{\circ} \mathrm{C}\right)$ and then injection in a DB-1 $60 \mathrm{~m}$ column, $0.32 \mathrm{~mm}$ i.d. with $1.0 \mu \mathrm{m}$ film. The temperature was set between -50 and $180{ }^{\circ} \mathrm{C}$, with heating rate of $6{ }^{\circ} \mathrm{C} \mathrm{min}^{-1}$. The sample was divided into two different detectors: mass spectrometer, in which the identification of compounds was made, and a flame ionization detector (FID), in which the quantification was performed, using a calibration curve with the NPL 30 EU Directive Ozone Precursor Mixture component at $20 \mathrm{ppb}$.

The analysis was performed by connecting the canister to a valve positioned at the inlet of the chromatograph; the air inside the canister was removed with the aid of a vacuum pump (Thomas Ind.). The sample was injected simultaneously into each of the two loops with a fixed sample volume associated with the gas chromatograph. Each chromatograph was equipped with its own cryogenic sample preconcentrator trap (SPT) at $-180^{\circ} \mathrm{C}$. After pre-concentration, the sample was sent to the chromatographic column by fast heating using helium as the carrier gas.

Carbonyl samples were collected and analyzed following the US EPA TO-11A methodology, ${ }^{10}$ based on the reaction of atmospheric carbonyls with 2,4-dinitrophenylhydrazine, to form the respective hydrazones. The samples were collected using two silica $\mathrm{C}_{18}$ cartridges in series impregnated with an acid solution of 2,4-dinitrophenilhydrazine (DNPH), using an air pump (KNF UNMP 850 KNDC) operated at $1.0 \mathrm{~mL} \mathrm{~min}{ }^{-1}$ for $60 \mathrm{~min}$. An ozone trap filled with potassium iodide was used before the DNPH cartridge to avoid ozone interference. After the sampling, the cartridges were sealed, wrapped with aluminum foil, stored at $4{ }^{\circ} \mathrm{C}$ and analyzed after 3 days. The detailed procedure is thoroughly explained in our previous work. ${ }^{11-13}$

The extraction of carbonyl samples was performed using $5 \mathrm{~mL}$ of acetonitrile and chemical analyses were completed with high-performance liquid chromatography (HPLC), using a Perkin Elmer Series 200 equipment with UV detection at $365 \mathrm{~nm}$. The mobile phase used was 55\% acetonitrile in water at $30^{\circ} \mathrm{C}$, with a $30 \mu \mathrm{L}$ volume and two 
$\mathrm{C}_{18}$ columns in series (250 mm (length), $4.6 \mathrm{~mm}$ (outside diameter) and $5.0 \mu \mathrm{m}$ (particle diameter)). Calibration was conducted using a standard mixture (Supelco CARB Carbonyl Mix 1) containing formaldehyde, acetaldehyde, acrolein, acetone, propionaldehyde, butyraldehyde and benzaldehyde at concentrations between 0.5 to $10.0 \mathrm{mg} \mathrm{L}^{-1}$, yielding correlation coefficients higher than 0.99 .

\section{Modeling procedure}

The modeling procedure was performed using the trajectory model OZIPR, which is widely accepted and well documented in the literature. ${ }^{5,14}$ Other publications by our group detail its applicability., ${ }^{3,15}$

OZIPR allows for simulating chemical and physical processes that occur in urban troposphere using a trajectory model. This model can be understood as a column of air at the base that encompasses the entire studied region, just up to the atmosphere mixing layer, similar to a box with a movable cover, which is a function of the mixture layer height throughout the day. The mixture layer height indicates the space where vertical dispersion of the pollutants is possible. The emissions from the base of the column are computed in addition to the wet and dry depositions. The ozone simulation study considers a homogeneous atmosphere, i.e., the pollutants do not suffer the interference of the air mass movement. In summary, the input data for a simulation are the following: (i) speciation of VOC of the local atmosphere in ppmC fractions; (ii) hourly emissions of total VOC, NOx and $\mathrm{CO}$ in $\mathrm{kg} \mathrm{km}^{-2} \mathrm{~h}^{-1}$; (iii) the initial concentrations of total VOC, NOx and CO in ppm; (iv) coefficients of wet and dry deposition for the main pollutants; (v) hourly weather data for temperature, pressure, humidity and mixing height; (vi) the actinic solar flux, used to calculate the intensity of the sunlight; and (vii) a chemical model with chemical reactions and their rate constants.

The output data are the hourly average concentrations of the main chemical species (e.g., $\mathrm{NOx}, \mathrm{CO}, \mathrm{CH}_{4}$, ozone, peroxyacetylnitrate (PAN)) and secondary pollutant isopleths for several values of VOC and NOx.

A simplified flow diagram for the construction of the model is shown in Figure 2.

The chemical model used was the 1999 version of the SAPRC model (Statewide Air Pollution Research Centre) developed by Carter; several updates were added in later years. ${ }^{4,16-21}$ The model was widely tested against 550 controlled experiments in Teflon chambers. The initial version used in this work has 214 reactions and 83 chemical species; 23 other chemical species and their reactions were recently introduced by our group, representing species that

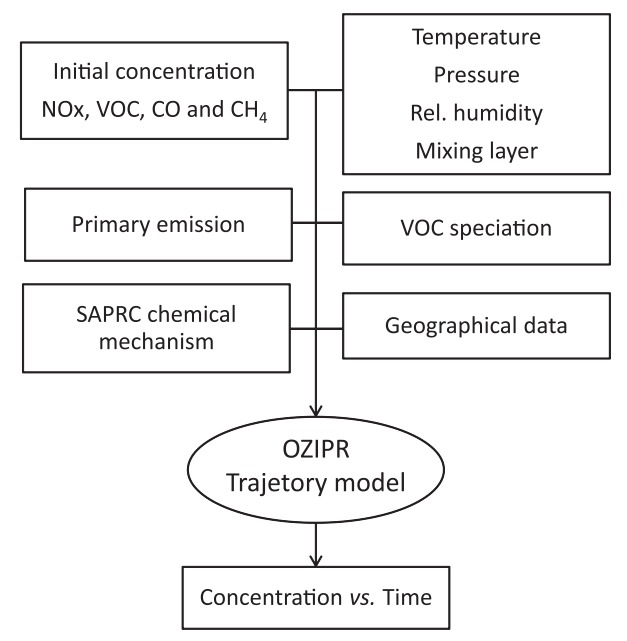

Figure 2. Simplified diagram of the OZIPR model coupled with SAPRC chemical mechanism.

frequently occur in Brazilian urban atmospheres such as ethanol, some alkenes and aromatics.

Ambient air criteria pollutant data (CO, NOx, NMHC, $\mathrm{O}_{3}$ ) were collected by an automated monitoring station during the Winter of 2011, located at the South part of Rio de Janeiro City, Brazil (22 $\left.58^{\prime} 44^{\prime \prime} S 43^{\circ} 13^{\prime} 58^{\prime \prime} \mathrm{W}\right)$, which also measured meteorological parameters (temperature, pressure and humidity). The location is adjacent to a large parking lot and is one of the busiest traffic routes in the city. It is also located next to the largest urban forest in the world, the Tijuca Forest.

The samples for VOC were collected by the automated monitoring station during the Winter (August and September 2011). Samples were collected in the first morning hours when the sunlight is at a minimum and the presence of secondary pollutants can be neglected.

Two canister samples were collected every 5 minutes, in 3 different days. Samples were collected from 6:45 am to 7.15 am on August 29, 6:40 am to 7:05 am on August 30 and 7:15 am to 7:30 am on September 6.

To validate the results obtained through computer simulations, it is necessary to prove that these results are closely approximate to actual conditions. The model used in this work was adjusted by comparing the simulated value with the values obtained experimentally. This procedure allows for the adjustment of factors for which data are lacking as horizontal and vertical dispersion and deposition rates.

To obtain the model adjustment, it is necessary to input meteorological parameters such as temperature and humidity, mixture layer height, $\mathrm{CO}, \mathrm{NOx}$ and VOC emissions in $\mathrm{kg} \mathrm{km}^{-1} \mathrm{~h}^{-1}$. These values were obtained from the annual emission inventory from the Rio de Janeiro State Environmental Agency (INEA). ${ }^{22}$ 
The first adjustment was performed on August 29 and an average value for the VOC speciation was used for the two samples collected. The same procedure was repeated on August 31 and September 6.

After model validation, the impact of motorcycles on the air quality of the Metropolitan Region of Rio de Janeiro (MRRJ) was evaluated from estimates of vehicular fleet increase using a polynomial fit of the number of motorcycles in the last 10 years. Thus, three different scenarios were created, varying from $\mathrm{CO}$, NOx and $\mathrm{HC}$ emissions obtained from a trend line of the increase in motorcycles in future use.

\section{Results and Discussion}

According to the INEA report, ${ }^{22} 321,000$ tons of CO, 90,500 tons of NOx and 79,300 tons of $\mathrm{HC}$ are emitted each year in MRRJ, which has an urban area of 2,400 km². To obtain the hourly emission calculations, a year was considered to have 313 days, excluding Sundays and holidays due to low circulation of vehicles on these days. For each day, $18 \mathrm{~h}$ of effective vehicle movement were considered. Thus, the hourly emission estimates were obtained and are shown in Table 2.

Table 2. Emissions from the Rio de Janeiro Metropolitan Area for $2009^{22}$

\begin{tabular}{lccc}
\hline \multirow{2}{*}{ Pollutant } & \multicolumn{3}{c}{ Emission } \\
\cline { 2 - 4 } & NOx & CO & VOC \\
\hline Annual emission / $\left(\mathrm{t} \mathrm{year}^{-1}\right)$ & 90,500 & 321,000 & 79,300 \\
Hourly emission $/\left(\mathrm{kg} \mathrm{h}^{-1} \mathrm{~km}^{-2}\right)$ & 6.693 & 23.74 & 5.865 \\
\hline
\end{tabular}

The results for the VOC speciation are detailed in Table 3. The hourly emissions of CO, NOx and VOC estimates (Table 2) were loaded into the model to reproduce experimental hourly concentrations of $\mathrm{CO}, \mathrm{NOx}$ and $\mathrm{O}_{3}$ provided by automatic monitors on August 29, 2011 (Table 4).

The first compound to be adjusted is $\mathrm{CO}$, as it is a primary pollutant with low reactivity. After performing the best possible fit, changing only the hourly $\mathrm{CO}$ emissions, a second adjustment was performed on the mixing layer height hourly values. It is important to remember that this adjustment is conducted around the average values obtained by the INEA emission inventory. ${ }^{22}$ Because the mixed layer height directly influences the pollutant concentrations, these values were adjusted to obtain the best possible fit between the simulated and measured $\mathrm{CO}$ concentration values. This value was taken as a basis for the mixing layer height and is the only measure recorded at 10:00 am in Rio de Janeiro City. Results for $\mathrm{CO}$ are presented in Figure 3.
After the simulated $\mathrm{CO}$ profile was adjusted against the experimental values, the next step was the adjustment of the NOx profile. This step was performed as an adjustment on hourly NOx emissions to reproduce the experimental values, similarly to that performed for $\mathrm{CO}$, without changing the profile of the mixed layer set above. To achieve a better adjustment of $\mathrm{CO}$ and NOx profiles, a final adjustment in their deposition rates was also made between the acceptable limits (1.0 to $1.5 \mathrm{~cm} \mathrm{~s}^{-1}$ for $\mathrm{CO}$, 0.10 to $0.20 \mathrm{~cm} \mathrm{~s}^{-1}$ for $\mathrm{NO}$ and 0.30 to $0.80 \mathrm{~cm} \mathrm{~s}^{-1}$ to $\left.\mathrm{NO}_{2}\right){ }^{8}$ Results for NOx are presented in Figure 3.

After adjusting the $\mathrm{CO}$ and NOx profiles, the next step was to adjust the simulated and experimental results for $\mathrm{O}_{3}$. As ozone is not emitted by any significant source, but rather formed by the reactions of VOC with NOx and sunlight, the adjustment was made by considering the hourly VOC emissions, while emissions of NOx were adjusted. As the model does not provide data on hourly concentrations of VOC, the adjustment in VOC emissions is achieved by adjusting the $\mathrm{O}_{3}$ profile.

The $\mathrm{O}_{3}$ adjustment presented the greatest difficulties to fit simulated and experimental values. To be able to increase the $\mathrm{O}_{3}$ level in the early hours, it was necessary to significantly increase the VOC and NOx emissions. However, changing these values contributed to a mismatch in the profile of NOx and an exaggerated increase in the $\mathrm{O}_{3}$ peak. Moreover, it was not possible to adjust the $\mathrm{O}_{3}$ profile after 1:00 pm. However, the $\mathrm{O}_{3}$ profile was modeled in other studies that also used OZIPR coupled with SAPRC S $^{3,11}$ and showed a similar profile to others modeled in this study. Therefore, the lag of the $\mathrm{O}_{3}$ maximum value was not considered relevant because the maximum $\mathrm{O}_{3}$ model concentrations and experimental concentrations showed strong agreement. Results for $\mathrm{O}_{3}$ are presented in Figure 3 .

The same procedure described above on August 29 was completed for the values found in the samples collected on August 31 and September 6. However, the results obtained were not satisfactory and were not used.

The experimental $\mathrm{CO}$ values for August 31 and September 6 deviated from the common data found for Rio de Janeiro City, with little variation throughout the day and without characteristic peaks in the early morning and late afternoon due to traffic and the low mixing layer height. Similar anomalous profiles were also observed on the same days for $\mathrm{NOx}$ and $\mathrm{O}_{3}$.

Another reason for using the data from August 29 was to validate the model and the anomalous values found for the meteorological data on the other two days. Temperature and relative humidity also showed little variation during the day and the presence of moderated winds may have contributed to this finding. 
Table 3. VOC speciation on August 29, 2011

\begin{tabular}{|c|c|c|c|}
\hline VOC & $\begin{array}{c}\text { Sample 1/ } \\
\left(\mu \mathrm{g} \mathrm{m}^{-3}\right)\end{array}$ & $\begin{array}{c}\text { Sample 2/ } \\
\left(\mu \mathrm{g} \mathrm{m}^{-3}\right)\end{array}$ & $\begin{array}{c}\text { Average / } \\
\left(\mu \mathrm{g} \mathrm{m}^{-3}\right)\end{array}$ \\
\hline Formaldehyde $^{a}$ & 10.34 & 13.2 & 11.77 \\
\hline Isobutane & 0.04 & 0.08 & 0.06 \\
\hline Acetaldehyde $^{a}$ & 3.18 & 4.66 & 3.92 \\
\hline Acetone $^{\mathrm{a}}$ & 3.80 & 4.02 & 3.91 \\
\hline Propanal $^{\mathrm{a}}$ & 1.12 & 1.27 & 1.19 \\
\hline 1-Butene & 2.01 & 3.09 & 2.55 \\
\hline 1,3-Butadiene & 1.75 & 2.15 & 1.95 \\
\hline Butane & 17.73 & 17.4 & 17.57 \\
\hline trans-2-Butene & 4.52 & 5.55 & 5.03 \\
\hline cis-2-Butene & 5.59 & 7.00 & 6.29 \\
\hline 3-Methyl-1-butene & 1.96 & 2.32 & 2.14 \\
\hline Isopentane & 21.05 & 20.6 & 20.83 \\
\hline Pentene & 8.41 & 10.4 & 9.41 \\
\hline 2-Methyl-2-butene & 16.34 & 17.1 & 16.72 \\
\hline Pentane & 15.14 & 17.4 & 16.27 \\
\hline Isoprene & 0.80 & 1.21 & 1.01 \\
\hline trans-2-Pentene & 19.39 & 23.5 & 21.45 \\
\hline cis-2-Pentene & 9.88 & 11.7 & 10.79 \\
\hline 1,1-Dimethyl cyclopropane & 28.35 & 27.5 & 27.92 \\
\hline 2,2-Dimethyl butane & 2.43 & 2.9 & 2.66 \\
\hline Cyclopentene & 3.32 & 4.41 & 3.87 \\
\hline Cyclopentane & 9.11 & 10.1 & 9.61 \\
\hline 2,3-Dimethyl butane & 6.25 & 6.22 & 6.24 \\
\hline 2-Methyl pentane & 27.80 & 26.4 & 27.10 \\
\hline Butanal $^{\mathrm{a}}$ & 2.36 & 2.09 & 2.23 \\
\hline 3-Methyl pentane & 17.73 & 20.1 & 18.92 \\
\hline 2-Methyl-1-pentene & 0.90 & 2.37 & 1.64 \\
\hline Hexene & 0.14 & 0.33 & 0.23 \\
\hline Hexane & 20.41 & 20.7 & 20.55 \\
\hline 3-Hexene & 1.60 & 1.56 & 1.58 \\
\hline 3-Methyl-2-pentene & 0.67 & 0.56 & 0.62 \\
\hline Methyl cyclopentane & 10.43 & 10.4 & 10.42 \\
\hline 4-Methyl-2-pentene & 1.68 & 1.44 & 1.56 \\
\hline
\end{tabular}

\begin{tabular}{|c|c|c|c|}
\hline VOC & $\begin{array}{l}\text { Sample } 1 / \\
\left(\mu \mathrm{g} \mathrm{m}^{-3}\right)\end{array}$ & $\begin{array}{c}\text { Sample 2/ } \\
\left(\mu \mathrm{g} \mathrm{m}^{-3}\right)\end{array}$ & $\begin{array}{c}\text { Average / } \\
\left(\mu \mathrm{g} \mathrm{m}^{-3}\right)\end{array}$ \\
\hline Benzene & 16.71 & 15.8 & 16.26 \\
\hline Cyclohexane & 1.75 & 1.35 & 1.55 \\
\hline 2-Methyl hexane & 1.43 & 1.17 & 1.30 \\
\hline 2,3-Dimethyl pentane & 0.47 & 0.45 & 0.46 \\
\hline 3-Methyl hexane & 1.80 & 2.07 & 1.94 \\
\hline cis-1,3-Dimethyl pentane & 0.31 & 0.33 & 0.32 \\
\hline Heptane & 1.39 & 1.20 & 1.29 \\
\hline Methyl cyclohexane & 0.76 & 0.67 & 0.71 \\
\hline Toluene & 24.10 & 24.60 & 24.35 \\
\hline 2-Methyl-heptane & 0.26 & 0.33 & 0.29 \\
\hline 3-Methyl-heptane & 0.28 & 0.23 & 0.25 \\
\hline Ethyl benzene & 5.76 & 5.50 & 5.63 \\
\hline Benzaldehyde ${ }^{a}$ & 2.67 & 2.55 & 2.61 \\
\hline p-Xylene & 11.17 & 10.70 & 10.94 \\
\hline$m$-Xylene & 13.57 & 12.40 & 12.99 \\
\hline Styrene & 4.32 & 4.05 & 4.19 \\
\hline$o$-Xylene & 10.71 & 10.40 & 10.56 \\
\hline Nonane & 0.62 & 0.78 & 0.70 \\
\hline Isopropyl benzene & 1.72 & 1.57 & 1.64 \\
\hline Propyl benzene & 1.07 & 1.08 & 1.08 \\
\hline 1-Ethyl-4-methyl benzene & 2.04 & 2.00 & 2.02 \\
\hline 1-Ethyl-3-methyl benzene & 1.45 & 1.44 & 1.44 \\
\hline 1,3,5-Trimethyl benzene & 1.55 & 1.87 & 1.71 \\
\hline 1-Ethyl-2-methyl benzene & 1.14 & 1.03 & 1.08 \\
\hline 1,2,4-Trimethyl benzene & 2.67 & 2.76 & 2.71 \\
\hline Decane & 0.76 & 0.94 & 0.85 \\
\hline 1,2,3-Trimethyl benzene & 1.27 & 1.12 & 1.19 \\
\hline Indane & 0.90 & 0.78 & 0.84 \\
\hline 1-Methyl-3-propyl benzene & 1.00 & 1.04 & 1.02 \\
\hline 4-Ethyl-1,2-dimethyl benzene & 1.16 & 1.48 & 1.32 \\
\hline Naphthalene & 0.90 & 1.05 & 0.97 \\
\hline Undecane & 0.27 & 0.33 & 0.30 \\
\hline Total & 392 & 413 & \\
\hline
\end{tabular}

${ }^{a}$ VOC sampled using TO-11A methodology. All other sampled using TO-15 methodology.

\section{Vehicular emission}

Due to difficulty in finding detailed information on the fleet of motorcycles in Brazil, a comparative study between the motorcycle emission rate used in this work and the light vehicular fleet in use today was conducted.

To estimate the real contributions of these vehicles regarding air quality, the survey was conducted in four stages. Initially, vehicle licensing inventory by make and model was consulted. ${ }^{23}$ According to this inventory, approximately $77 \%$ of the fleet consists of vehicles manufactured by four companies: Fiat, Ford, General Motors and Volkswagen.

The second step was to observe the amount of sales per model ${ }^{24}$ which indicates that the best-selling car models in the country were the following: Gol, Uno, Palio, Celta, Fox, Corsa Sedan and Fiesta.

In the third step, the emission rates for the bestselling models and the average values were verified and consolidated in Table 5 . 
Table 4. Hourly average experimental values on August 29, 2011. VOCs were sampled from 6:45 am to 7:15 am

\begin{tabular}{lccccc}
\hline \multirow{2}{*}{ Hour } & \multicolumn{3}{c}{ Emission } & \multicolumn{2}{c}{ Meteorological data } \\
\cline { 2 - 6 } & $\mathrm{CO} /\left(\mu \mathrm{g} \mathrm{m}^{-3}\right)$ & $\mathrm{NOx} /\left(\mu \mathrm{g} \mathrm{m}^{-3}\right)$ & $\mathrm{O}_{3} /\left(\mu \mathrm{g} \mathrm{m}^{-3}\right)$ & Temperature $/{ }^{\circ} \mathrm{C}$ & $\mathrm{RH} / \%$ \\
\hline $06: 30$ & 0.09 & 75.08 & 3.99 & 21.34 & 27.02 \\
$07: 30$ & 0.42 & 112.76 & 15.17 & 29.80 & 43.06 \\
$08: 30$ & 0.06 & 79.10 & 29.17 & 31.43 & 34.34 \\
$09: 30$ & 0.14 & 106.78 & 26.86 & 32.28 & 31.78 \\
$10: 30$ & 0.10 & 84.71 & 41.71 & 33.44 & 31.28 \\
$11: 30$ & 0.08 & 76.15 & 64.97 & 34.66 & 29.15 \\
$12: 30$ & 0.09 & 69.88 & 86.40 & 33.74 & 29.11 \\
$13: 30$ & 0.13 & 63.45 & 91.07 & 31.63 & 35.09 \\
$14: 30$ & 0.08 & 48.83 & 73.49 & 31.55 & 42.34 \\
$15: 30$ & 0.10 & 64.8 & 51.31 & 30.58 & 42.45 \\
$16: 30$ & 0.22 & 66.62 & 33.89 & 26.89 & 46.87 \\
$17: 30$ & 0.53 & 94.13 & 9.07 & 25.23 & 61.04 \\
\hline
\end{tabular}

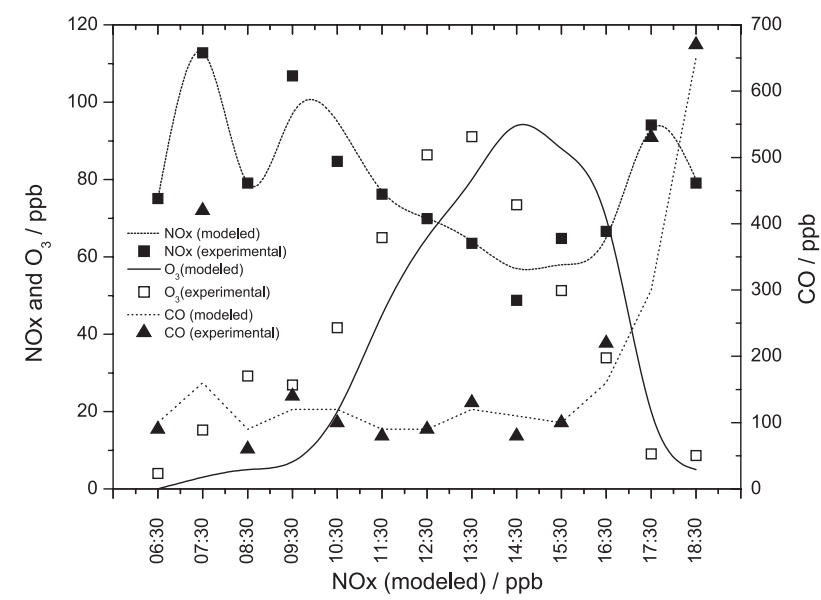

Figure 3. Results for experimental and modeled values of $\mathrm{O}_{3}, \mathrm{CO}$ and NOx on August 29, 2011.

Table 5. Average CO, NOx and NMHC emission rates for the best-selling vehicles

\begin{tabular}{lccc}
\hline \multirow{2}{*}{ Company } & \multicolumn{3}{c}{ Emission } \\
\cline { 2 - 4 } & $\begin{array}{c}\mathrm{CO} / \\
\left(\mathrm{g} \mathrm{km}^{-1}\right)\end{array}$ & $\begin{array}{c}\mathrm{NOx} / \\
\left(\mathrm{g} \mathrm{km}^{-1}\right)\end{array}$ & $\begin{array}{c}\mathrm{NMHC} / \\
\left(\mathrm{g} \mathrm{km}^{-1}\right)\end{array}$ \\
\hline Volkswagen & 0.573 & 0.040 & 0.033 \\
FIAT & 0.403 & 0.037 & 0.034 \\
GM & 0.963 & 0.062 & 0.054 \\
FORD & 0.441 & 0.036 & 0.033 \\
Average & 0.595 & 0.044 & 0.039 \\
\hline
\end{tabular}

Automobiles and motorcycles constitute approximately $88 \%$ of the fleet in Rio de Janeiro City. Thus, the estimated emission rates of these two types of vehicles can be considered representative of the whole of the current fleet..$^{23}$

\section{Scenario study}

For the creation of the scenarios, it is necessary to estimate the expected emission increase from motorcycles. Unfortunately, there is no database available for CO, NOx and HC emissions for motorcycles as there is for light vehicles. Thus, the average emission values of two standard motorcycles were used, as described in the section for the dynamometer tests.

Table 6. Emission rate results for $\mathrm{CO}$, NOx and NMHC for two standard motorcycles

\begin{tabular}{lccc}
\hline Motorcycle & \multicolumn{3}{c}{ Emission } \\
\cline { 2 - 4 } & $\begin{array}{c}\mathrm{CO} / \\
\left(\mathrm{g} \mathrm{km}^{-1}\right)\end{array}$ & $\begin{array}{c}\mathrm{NOx} / \\
\left(\mathrm{g} \mathrm{km}^{-1}\right)\end{array}$ & $\begin{array}{c}\mathrm{NMHC} / \\
\left(\mathrm{g} \mathrm{km}^{-1}\right)\end{array}$ \\
\hline BK02 & 0.723 & 0.071 & 0.180 \\
BK01 & 0.680 & 0.060 & 0.170 \\
Average & 0.702 & 0.066 & 0.175 \\
\hline
\end{tabular}

A comparison between average motorcycle (Table 5) and light vehicle (Table 4) emission data is presented in Figure 4. It is important to remember that it is a conservative study, as the two evaluated motorcycles are new and comply with the last phase of PROMOT.

Despite the difference in the methodologies used to measure the emissions (Directive 97/24/EC of the European Parliament and of the Council of 17 June 1997 on certain components and characteristics of two or three-wheel motor vehicles for motorcycles and ABNT NBR 6601 - Road vehicles - Determinations of hydrocarbon, carbon monoxide, nitrogen oxide, carbon dioxide and particulate material on exhaust gas, 2005, for light vehicles), the average emissions found for the two motorcycles indicate higher concentrations 


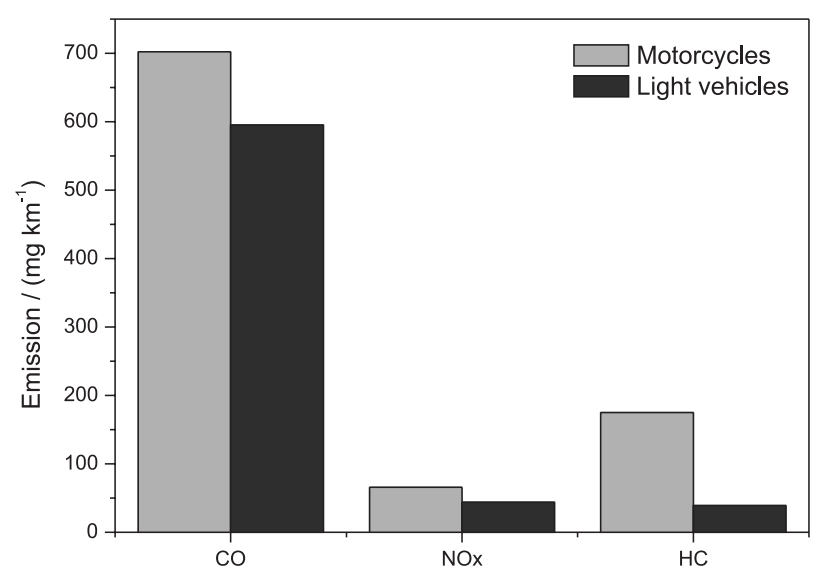

Figure 4. Comparison of emissions of motorcycles and light vehicles.

for ethene, propene, ethyne, pentane, benzene and toluene. All of these pollutants presented average emission rates above $4 \mathrm{mg} \mathrm{km}^{-1}$.

Regarding the fleet increase, which presents a quantitative history of motorcycles in use in Rio de Janeiro, a chart with a fleet growth trend line was prepared (Figure 5). From this graph, it was possible to obtain the estimated numbers of motorcycles for the next 3, 5 and 10 years starting from October 2011.

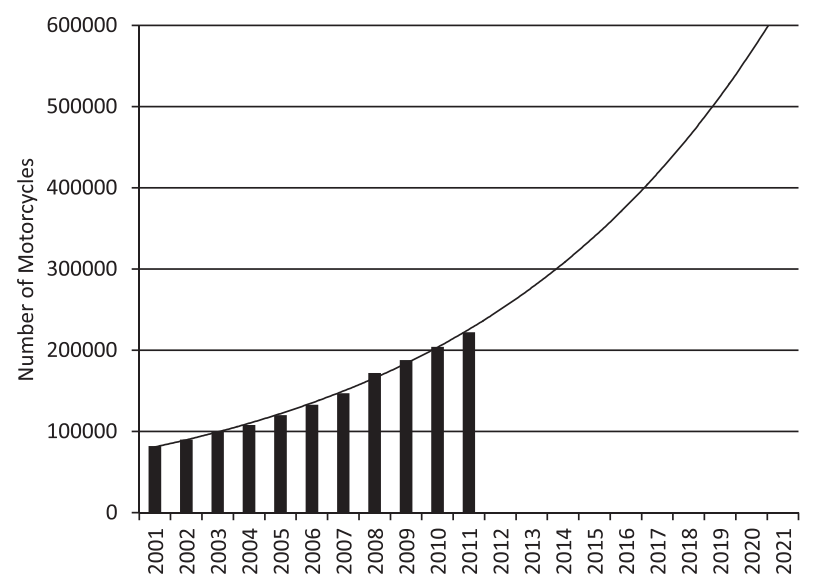

Figure 5. Trendline for the motorcycle fleet increases for the next 3,5 and 10 years in the Rio de Janeiro City.

According to Figure 5, the motorcycle fleet will number approximately 300,000 in 2014, representing an increase of $34 \%$ over the year 2011. Two years later, the increase will be almost $61 \%$, to 360,000 motorcycles. Finally, in 10 years, the fleet growth will be approximately $132 \%$, with approximately 520,000 motorcycles in circulation.

Based on these data, three scenarios with simulations to estimate the impact for the next 3,5 and 10 years were created.

To conduct scenario studies, some assumptions are required. The atmosphere of a city is a combination of numerous parameters, such as emissions, topography, meteorology and others. To choose a hypothetical scenario for a future condition of a city, it is not possible to assume changes in all parameters simultaneously because the associated errors may increase or even vanish. Thus, the study of scenarios here will take into account the following assumptions: $(i)$ data on August 29 were used to fit the model (profiles of temperature, humidity, mixing layer and deposition rates); (ii) the VOC speciation of August 29 was used; (iii) the fleet increase of light or heavy vehicles was not considered; (iv) a possible variation in the composition of fuels used was not considered; and $(v)$ future reductions in emissions from vehicles and motorcycles that will surely be implemented in the future were not considered.

Thus, increases in $\mathrm{CO}, \mathrm{HC}$ and $\mathrm{NOx}$, arising from an increased motorcycle fleet, will be computed on the basis of their percentage in the fleet, where the hourly emissions used in the adjustment of the model are weighed by increased emissions and the percentage of the fleet in MRRJ.

Assuming an increased motorcycle fleet, there will be a larger percentage of each scenario, as the vehicles have stabilized in number. The current percentage of the motorcycles in MRRJ is $11.68 \%$. Thus, the estimated percentage of motorcycles in three years is $15.65 \%$, in 5 years $18.81 \%$ and in 10 years $27.10 \%$.

It is also necessary to take into consideration that an increase in the motorcycle fleet will not lead to a linear increase in $\mathrm{CO}, \mathrm{NOx}$ and $\mathrm{HC}$, as motorcycles have higher emission rates for all pollutants, for instance, $13.44 \%$ higher than the vehicles for CO, $36.36 \%$ for NOx and $336 \%$ for HC. All the factors are computed and presented in Table 7.

Table 7. Emissions for each proposed scenario

\begin{tabular}{lccc}
\hline \multirow{2}{*}{ Scenario } & \multicolumn{3}{c}{ Emission } \\
\cline { 2 - 4 } & $\begin{array}{c}\mathrm{CO} / \\
\left(\mathrm{kg} \mathrm{h}^{-1} \mathrm{~km}^{-2}\right)\end{array}$ & $\begin{array}{c}\mathrm{NOx} / \\
\left(\mathrm{kg} \mathrm{h}^{-1} \mathrm{~km}^{-2}\right)\end{array}$ & $\begin{array}{c}\mathrm{HC} / \\
\left(\mathrm{kg} \mathrm{h}^{-1} \mathrm{~km}^{-2}\right)\end{array}$ \\
\hline 1 & 6.728 & 23.740 & 6.424 \\
2 & 6.756 & 23.998 & 6.869 \\
3 & 6.830 & 24.682 & 8.049 \\
\hline
\end{tabular}

The results for the ozone concentration profile in the troposphere for the studied scenarios are shown in Figure 6.

In Figure 6, one can see that the increase of the motorcycle fleet implies a significant increase in the ozone concentration in the troposphere. This increase is due to the high hydrocarbon emission rate inherent in the operation of motorcycles compared to that of light vehicles.

Currently, the ozone concentration in the troposphere of Rio de Janeiro City is relatively low, as it is routinely 


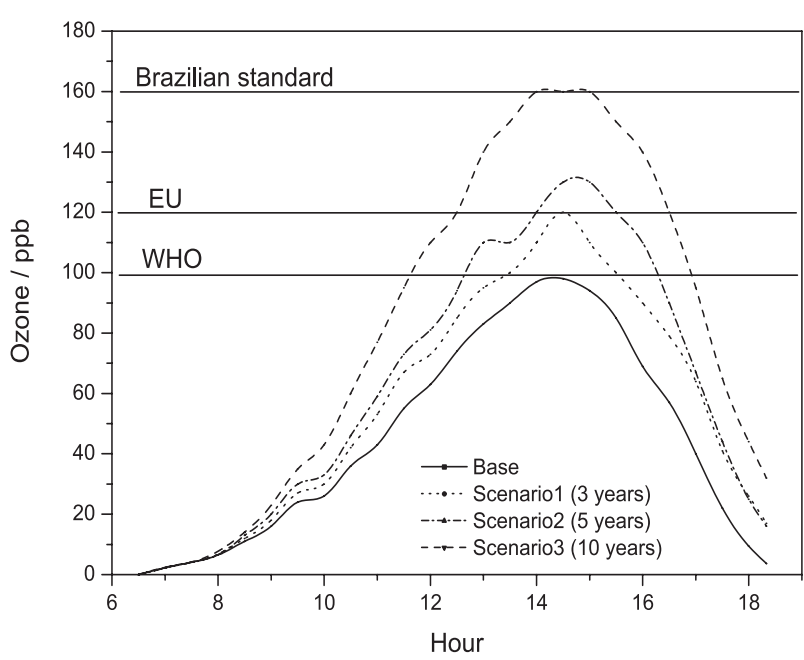

Figure 6. Ozone profile modeled for each proposed scenario.

below $100 \mathrm{ppb}$. This fact stems from the high concentration of NOx found.

According to the model results for the chosen scenarios, the highest ozone values were recorded around 2:30 pm, reaching $120 \mathrm{ppb}$ for scenario $1,130 \mathrm{ppb}$ for scenario 2 and $160 \mathrm{ppb}$ for scenario 3 . Regarding air quality standards in accordance with those seen in Figure 6, one can predict that the reference values, national and international, will be exceeded in approximately three years. One exception to this estimate is the standard used by the US EPA ( $320 \mathrm{ppb})$, which will not be reached.

Besides the studied scenario results, the model was also used in multiple simulations for different maximum ozone concentrations of several VOC and NOx concentrations, providing data that generate an isopleth plot (lines of equal concentrations).

In Figure 7, isopleths for maximum ozone levels of the base case can be viewed. The figure shows a scenario with

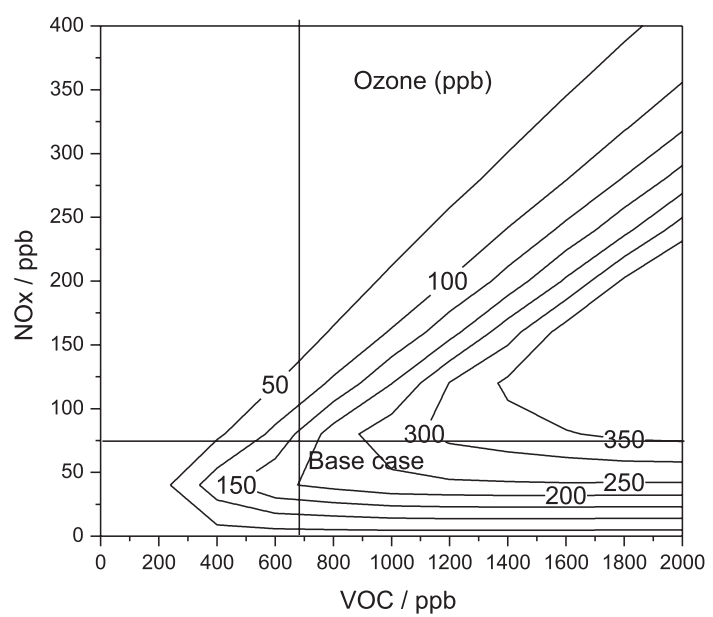

Figure 7. Ozone isopleth plot (ppb) for several concentrations of VOC and NOx for the base case on August 29, 2011. little variation in the NOx rate plus a large addition of VOC, resulting in significant increases in ozone.

\section{Conclusions}

From the results obtained in this work, a significant deterioration in air quality in large cities is expected due to increases in motorcycle fleets in urban centers and the consequent increase in emissions. In 2001, the number of motorcycles (approximately 82,000) was less than $5 \%$ of the vehicular fleet of Rio de Janeiro City. In ten years, that number is expected to exceed a rate of $9 \%$ of the total fleet (approximately 224,000) and is growing steadily.

The results of VOC speciation emitted from motorcycles indicated high emission rates for very reactive species such as ethene, propene, ethyne, pentane, benzene and toluene. All of these pollutants presented average emission rates higher than $4 \mathrm{mg} \mathrm{km}^{-1}$.

The determined results indicate that the $\mathrm{O}_{3}$ concentration in the troposphere will exceed the national standard established by the CONAMA Resolution 03/90 within three years. ${ }^{25}$ It also indicates that the emission rates of motorcycles used in this study (HC, CO and NOx) already meet the levels recommended in all phases of PROMOT. Thus, in addition to the adoption of PROMOT, additional actions are necessary to manage the pollutant emission generated from mobile sources.

\section{Acknowledgements}

This work was partially supported by Fundação de Amparo à Pesquisa do Estado do Rio de Janeiro (FAPERJ) and Conselho Nacional de Desenvolvimento Científico e Tecnológico (CNPq).

\section{References}

1. CETESB; Qualidade do Ar no Estado de São Paulo 2011, http:// www.cetesb.sp.gov.br/ar/qualidade-do-ar/31-publicacoes-erelatorios accessed in September 2012.

2. http://www.detran.rj.gov.br/_estatisticas.veiculos/02.asp accessed in January 2012.

3. Orlando, J. P.; Gatti, L. V.; Alvim, D. S.; Yamazaki, A.; Corrêa, S. M.; Sci. Total Environ. 2010, 408, 1612.

4. Carter, W. P. L.; Atmos. Environ. 1990, 24, 481.

5. Gery, M. W.; Crouse, R. R.; User's Guide for Executing OZIPR, EPA-9D2196NASA; US Environmental Protection Agency, Research Triangle Park: North Carolina, USA, 1990.

6. Guimarães, C. S.; Arbilla, G.; Corrêa, S. M.; Gatti, L. V.; Tchê Química 2007, 4, 21. 
7. Campos, I. C. B.; Pimentel, A. S.; Corrêa, S. M.; Arbilla, G.; J. Braz. Chem. Soc. 1999, 10, 203.

8. Finlayson-Pitts, B. J.; Pitts Jr., J. N.; Chemistry of the Upper and Lower Atmosphere: Theory, Experiments and Spplications; Academic Press, 1999.

9. United States Environmental Protection Agency (US EPA); Determination of Volatile Organic Compounds (VOCs) in Air Collected in Specially-Prepared Canisters and Analyzed by Gas Chromatography/Mass Spectrometry (EPA/625/R-96/010b), $2^{\text {nd }}$ ed., Compendium Method TO-15A; Center for Environmental Research Information: Cincinnati, OH, USA, 1999.

10. United States Environmental Protection Agency (US EPA); Determination of Formaldehyde in Ambient Air Using Adsorbent Cartridge Followed by High Performance Liquid Chromatography (HPLC) (EPA-625/R-96/010b), Compendium Method TO-11A; Center for Environmental Research Information: Cincinnati, OH, USA, 1997.

11. Corrêa, S. M.; Arbilla, G.; Marques, M. R. C.; Oliveira, K. M. P. G.; Atmos. Pol. Res. 2012, 3, 163.

12. Corrêa, S. M.; Arbilla, G.; Martins, E. M.; Quiterio, S. L.; Guimaraes, C. S.; Gatti, L. V.; Atmos. Environ. 2010, 44, 2302.

13. Corrêa, S. M.; Arbilla, G.; Atmos. Environ. 2003, 37, 23.

14. Tonnesen, G. S; 2000; User's Guide for Executing OZIPR, version 2.0; US EPA: North Carolina, USA, 2000.

15. Corrêa, S. M.; Souza, C. V.; Sodré, E. D.; Teixeira, J. R.; J. Braz. Chem. Soc. 2012, 23, 496.

16. Carter, W. P. L.; Atmos. Environ. 1995, 29, 2513.

17. Carter, W. P. L.; Atmos. Environ. 1996, 30, 4275.
18. Carter, W. P. L.; Documentation of the SAPRC-99 Chemical Mechanism for VOC Reactivity Assessment; Report to the California Air Resources Board, Contracts 92-329 and 95-308, USA, 2000.

19. Carter, W. P. L.; Luo, D.; Malkina, I. L.; Environmental Chamber Studies for Development of an Updated Photochemical Mechanism for VOC Reactivity Assessment; Report to the California Air Resources Board, Contract 92-345, Coordinating Research Council, Inc., Project M-9, and Coordinating Research Council, Inc., Project M-9, USA, 1997.

20. Carter, W. P. L.; Lurmann, F. W.; Atmos. Environ. 1991, 25, 2771.

21. Carter, W. P. L.; Atkinson, R.; Int. J. Chem. Kinet. 1996, 28, 497.

22. Rio de Janeiro State Environmental Institute (INEA); Annual Report 2009; INEA: Rio de Janeiro, Brazil, 2009.

23. http://www.anfavea.com.br/tabelas.html accessed in November 2012.

24. http://www.fenabrave.org.br accessed in November 2012.

25. Conselho Nacional Do Meio Ambiente (CONAMA); Sets Standards of Primary and Secondary Air Quality and Even the Criteria for Acute Episodes of Air Pollution, Resolution No. 03 of 28 June, 1990; Official Journal of the Federative Republic of Brazil: Brasilia, DF, Brazil, 1990.

Submitted: June 19, 2012

Published online: February 26, 2013

FAPESP has sponsored the publication of this article. 